\title{
"Gorki okus tkanine” - zagrebačka i jugoslavenska tekstilna industrija 1960-ih u svjetlu odabranih hrvatskih tiskovina
}

\author{
TIHANA PETROVIĆ LEŠ
}

Filozofski fakultet u Zagrebu, Odsjek za etnologiju i kulturnu antropologiju Zagreb, Hrvatska

tples@ffzg.hr

\author{
ANDREA KLOBUČAR \\ Muzej za umjetnost i obrt \\ Zagreb, Hrvatska \\ andrea.klobucar@muo.hr
}

\begin{abstract}
Analitičko-interpretativnom metodom tekstova iz odabranih tiskovina obrađena je zagrebačka i jugoslavenska tekstilna industrija u razdoblju od 1959. do 1971./1972. godine. Zbog opsega i zahtjevnosti teme obuhvaćena je samo proizvodnja tekstila u metraži, koja je činila temelje i bila glavni proizvod tekstilne industrije šezdesetih godina. Suprotno uvriježenome mišljenju da su šezdesete u Jugoslaviji zlatno doba ekonomije, tekstilne industrije, mode i političkih sloboda, autorice upozoravaju na svakodnevne i strukturne probleme tekstilne industrije.
\end{abstract}

Ključne riječi: tekstilna industrija; Jugoslavija; Zagreb; tiskovine; gospodarska povijest; 1960-e

\section{Uvod}

Razdoblje „šezdesetih” u Hrvatskoj aktualna je i izazovna istraživačka tema različitih znanstvenih disciplina. Pritom je znatan interes pokazan za jedno karakteristično obilježje - odijevanje, kao i sve povezano s njime. Neki aspekti industrijske proizvodnje, potrošnje tekstila i konfekcije dotaknuti su u radovima koji se bave istraživanjima ekonomske i gospodarske povijesti, ${ }^{1}$ svakodnevnoga života, potrošačke kulture i slobodnoga vremena. ${ }^{2}$ Kulturno an-

1 JAKIR, „Nemoguća misija i početak kraja?”, 91-110. Pregled historiografije ekonomske i gospodarske povijesti daje Josip Mihaljević u: MIHALJEVIĆ, „Ekonomska povijest u Časopisu za suvremenu povijest (1969. - 2018.)", 741-784.

2 DUDA, U potrazi za blagostanjem; DUDA, Pronađeno blagostanje. 
tropološka i rodna istraživanja obuhvatila su širok aspekt problema tekstilne industrije u Hrvatskoj od poslijeratne industrijalizacije do postsocijalističke deindustrijalizacije. ${ }^{3}$ Interdisciplinarni muzeološki projekt „Šezdesete u Hrvatskoj - Mit i stvarnost" ponudio je prikaz različitih aspekata jugoslavenskoga socijalističkog društva 60-ih, a tekstilna problematika bila je usmjerena samo na modu. ${ }^{4}$ Drugi veći izložbeni projekt, „Moda i odijevanje u Zagrebu 1960-ih”, bio je usmjeren na prikaz tekstilne industrije, obrtništva i kućne proizvodnje tekstila na području Zagreba, tadašnjega centra hrvatske tekstilne industrije. ${ }^{5}$ Tijekom pripreme tekstova, kao pozvane suradnice za potrebe spomenute izložbe, utvrdile smo da nedostaju temeljni prikazi tekstilne industrije od 1945. do 1991., što je dovelo do toga da se to pitanje interpretira stereotipnom pozitivnom slikom kao jedan od pokazatelja socijalističkih uspjeha. U radu, obrađujući jedan segment tekstilne industrije u kraćem razdoblju, dajemo doprinos boljem poznavanju ovoga dijela gospodarske povijesti.

Do sada se smatralo da je tekstilna industrija u socijalističkom razdoblju doživjela pravi „modni i proizvodni boom”. ${ }^{6}$ Takav dojam o velikom razvitku tekstilne industrije stječe se s aspekta današnjice, kada je tekstilna industrija u Hrvatskoj gotovo zamrla. ${ }^{7}$ Razlikujući tekstilnu industriju kao opći pojam i tekstilnu konfekciju kao njezin sastavni dio koji uključuje izradu rublja i gornje odjeće, ${ }^{8} \mathrm{u}$ nastavku se bavimo proizvodnjom tekstila u metraži, u tom razdoblju glavnoga proizvoda, koja je činila temelje tekstilne industrije. S njom usko povezana industrija konfekcije zasebna je tema koja ima drukčiju dinamiku i razvoj te postaje dominantnija grana tekstilne industrije tek krajem 60 -ih i tema je zasebnoga istraživanja. ${ }^{9}$

Predmet je ovoga rada zagrebačka metražna tekstilna industrija 60-ih godina XX. stoljeća u kontekstu jugoslavenske tekstilne industrije. Zbog složenosti teme kronološki prikazujemo tekstilnu industriju prema već uvrije-

3 BONFIGLIOLI, „A Working Day that has no End”; SENJKOVIĆ, „Ugljen i šminka”, 174-193; MAKSIĆ, MATOŠEVIĆ, „Kad si opušten, tada možeš dati sve od sebe”, 95-110; PREMUŽ ĐIPALO, „Žene u doba socijalizma”, 159-192; ČULJAK, VENE, „Žena u borbi / Žena u modi”, 159-173; PAVLINUŠIĆ, Što je nama naša Dalmatinka dala?; MATEŠ, Šezdesete u Zagrebu; SIMONČIČ, „Modni boom - revolucija modnih izričaja”, 328-355; TEŽAK, Stoljeće tekstila 1918. - 2018.

4 Izložba je održana u Muzeju za umjetnost i obrt od 26. travnja do 30. rujna 2018. godine. Povodom izložbe izdan je istoimeni katalog: LEDIĆ, PRLIĆ, VUČIĆ, Šezdesete u Hrvatskoj: mit i stvarnost.

5 Izložba je održana u Muzeju grada Zagreba od 26. veljače do 19. svibnja 2019. godine. Voditeljica projekta i autorica izložbene koncepcije je viša kustosica Maja Arčabić, voditeljica Zbirke tekstila i namještaja. U okviru izložbe sudjelovale smo u dionicama „Zagrebačka tekstilna i konfekcijska industrija” i „Zagrebačke šnajderice”. Istraživanja su provedena od srpnja 2018. do kraja ožujka 2019. godine.

6 SIMONČIČ, „Modni boom - revolucija modnih izričaja”, 331; SIMONČIČ, „Modni oglas - memorijski zapis tekstilne i odjevne produkcije Varteksa", 62.

7 MILAT, „Spora smrt tekstilne industrije”.

8 „Tekstil i konfekcija”, 708.

9 Autorice su za potrebe izložbe i pratećega kataloga Moda i odijevanje u Zagrebu 1960-ih obradile konfekcijsku industriju u Zagrebu. Tekstovi su u postupku pripreme za objavu. 
ženim povijesnim podjelama toga razdoblja, utemeljenim na gospodarskim, političkim i ekonomskim procesima, naslanjajući se na pristup Zdenke Šimončić-Bobetko u obradi tekstilne industrije u međuraću. ${ }^{10}$ Da bismo shvatili složenost problematike tekstilne industrije 60 -ih, potrebno je obuhvatiti nešto šire razdoblje, kako je već prihvaćeno u historiografiji, od kraja 50-ih do početka 70 -ih. ${ }^{11}$

Analitičko-interpretativnom metodom rada na tekstovima iz onodobnoga tiska otkrivaju se brojni problemi, čak suprotnosti: s jedne strane velik je broj novootvorenih tekstilnih tvornica i novozaposlenih radnika, a s druge strane istodobno tekstilci ostvaruju male ukupne prihode i stječu najmanji osobni dohodak među svim industrijama. Istraživanje temeljimo na podatcima iz novina i časopisa od 1959. do 1972. kao što su revijalna izdanja zagrebačke izdavačke kuće Vjesnik: obiteljski tjednik Arena, modna revija Svijet, revija za televiziju, radio, film i kazalište Studio, tjednik za djecu i mlade Plavi vjesnik, polumjesečna ilustrirana revija Start, zagrebački ilustrirani tjednik Globus, zatim gospodarski tjednik Privredni vjesnik: list za privredna pitanja, hrvatski tjednik Vjesnik u srijedu (VUS) i Tekstil: savezni stručni časopis za tekstilnu tehnologiju i konfekciju. ${ }^{12}$ Takvim odabirom tiskovina dobiven je uvid u širok spektar ekonomskih, tehnoloških, tržišnih i drugih problema. Na taj je način dobivena potpunija i realnija slika tekstilne industrije 60-ih. Za potrebe ovoga rada od veće su koristi bili Privredni vjesnik i VUS, koji su donosili analitičke i kritičke tekstove o tekstilnoj industriji u Jugoslaviji i Hrvatskoj iz kojih se iščitava sva složenost ekonomskih, društvenih i političkih prilika.

Izvori su omogućili više podataka o dvjema zagrebačkim tvornicama metraže, Zagrebačkoj industriji svile (ZIS) i Pobjedi, koje smo koristile kao male studije slučaja. U tekstu u kratkim crtama prikazujemo tradiciju proizvodnje tekstilne metraže u međuraću i od 1945. do 1959., a zatim pozornost usmjeravamo na razdoblje od 1959. do 1965. te od 1965. do 1971. godine.

\section{Uvodne napomene o zagrebačkoj tekstilnoj metražnoj industriji}

Tradicija proizvodnje tekstila u Zagrebu postoji od posljednje četvrtine XIX. stoljeća, a ubrzaniji razvoj doživljava u međuraću. ${ }^{13}$ To vrijeme intenzivne industrijalizacije u tekstilnoj industriji u Hrvatskoj, s obzirom na gospodarsku, ekonomsku i političku situaciju, povjesničarka Zdenka Šimon-

10 ŠIMONČIĆ-BOBETKO, „Razvoj tekstilne industrije u Hrvatskoj”, 101-203.

11 U našoj historiografiji u posljednje vrijeme pod 60-ima se obrađuje razdoblje od 1958. do 1971./1972. Vidi opširnije u: MIHALJEVIĆ, Komunizam i čovjek; LEDIĆ, PRLIĆ, VUČIĆ, Šezdesete u Hrvatskoj: mit i stvarnost.

12 Periodika je odabrana i zadana u okviru projekta „Moda i odijevanje u Zagrebu 1960ih”. Tekstove su napisali uglavnom nepotpisani ili inicijalima, rijetko punim imenom i prezimenom potpisani autori. Vidi: RADELIĆ, Hrvatska u Jugoslaviji 1945. - 1991., 370.

13 KLOBUČAR, „... u dobru i zlu...”Vjenčana odjeća od 1865. do danas, 37. 
čić-Bobetko podijelila je na četiri razdoblja prema njihovim posebnostima. ${ }^{14}$ Tekstilne tvornice u međuraću uglavnom su bile utemeljene na stranom kapitalu (austrijskom, češkom, njemačkom i švicarskom). Istodobno se uvozilo velike količine gotove metraže iz Italije i Čehoslovačke. ${ }^{15}$ Prve zagrebačke tvornice tekstilne metraže osnovane nakon 1918. bile su Tvornica za pamučnu industriju Hermann Pollak \& $\operatorname{sinovi}^{16}$ (1923.), Pamuk d.d. (1927.), Jugoslavenska tekstilna tvornica Braća Holzner d.d. (1928.), ${ }^{17}$ Lana - industrija vunene robe (1928.), Svila - tekstilna industrija Janowski i Porecki k.d. (1928.), ${ }^{18}$ tkaonica svile S. Trebić i sin k.d. (1934.), ${ }^{19}$ Zora - predionica i tkaonica vune (1934.) i Tvornica vunenih tkanina Schindel - H. Jakob u Kustošiji (1935.). ${ }^{20}$ U međuraću je tekstilna industrija zapošljavala $66 \%$ žena, pretežito sa zagrebačke periferije, koje su živjele i radile u nehigijenskim i teškim uvjetima uz slabe plaće. ${ }^{21}$ Od 30 -ih godina XX. stoljeća žene su se organizirale u različite oblike sindikalnih, političkih, građanskih i vjerskih organizacija s ciljem poboljšanja radničkih prava. U tim su se aktivnostima osobito isticale radnice zagrebačkih tvornica svile. ${ }^{22}$

Mreža tvornica iz međuraća postala je temeljem razvoja tekstilne industrije u Zagrebu nakon Drugoga svjetskog rata te se razvijala i poslovala $u$ kontekstu tadašnje hrvatske, odnosno šire jugoslavenske industrije. Postojeće tekstilne tvrtke poput Industrije vunenih tkanina Zora, ZIS-a, Tvornice za pamučnu industriju (TVORPAM), Tvornice konca Unitas, većinom koncentrirane na rubnim dijelovima grada, prelaze u državno vlasništvo i dalje nastavljaju povećavati i industrijalizirati svoju proizvodnju kao dio napora

14 ŠIMONČIĆ-BOBETKO, „Razvoj tekstilne industrije u Hrvatskoj”, 153-174. Odredila je četiri razdoblja razvoja hrvatske tekstilne industrije u kontekstu jugoslavenske: prvo od 1918. do 1924., drugo od 1925. do 1929., treće od 1930. do 1934. i četvrto od 1935. do 1940. godine. Inženjerka tekstilne tehnologije i inženjerstva Ivana Biočina, za razliku od Zdenke Šimončić-Bobetko, pojednostavnjeno dijeli cijelu povijest tekstilne industrije u Hrvatskoj od početka XX. stoljeća do danas na pet razdoblja, bez jasnih odrednica prema kojima je podjela napravljena. Razlikuje početke tekstilne industrije početkom XX. stoljeća, industriju od 1935. do Drugoga svjetskog rata, potom industriju od sredine stoljeća do 1989., a nakon toga tranzicijsko razdoblje u novo stoljeće i suvremenu tekstilnu industriju. Vidi: BIOČINA, Proizvedeno u Hrvatskoj.

15 ŠIMONČIĆ-BOBETKO, „Razvoj tekstilne industrije u Hrvatskoj”, 150-158; KOLAR DIMITRIJEVIĆ, „Zagrebačke tvornice svile”, 81-84.

16 Felix Pollack osnovao je 1923. u Zagrebu podružnicu bečke tvrtke Hermann Pollack's Söhne. ŠIMONČIĆ-BOBETKO, „Razvoj tekstilne industrije u Hrvatskoj”, 167, 182; na stranici tvrtke sljednice, Tvornice tekstila Trgovišće, navedena je 1924. godina. Tvrtku Hermann Pollack's Söhne osnovao je početkom 1830-ih Felixov djed Hermann. Vidi u: EIGNER, „Pollack von Parnegg, Leopold Freiherr”.

17 ŠIMONČIĆ-BOBETKO, „Razvoj tekstilne industrije u Hrvatskoj”, 182.

18 Isto, 189.

19 Isto, 165.

20 Isto, 189.

21 KOLAR DIMITRIJEVIĆ, „Zagrebačke tvornice svile”, 110, 133; KOLAR DIMITRIJE-

VIĆ, Radni slojevi Zagreba od 1918. do 1931.; ŽEBEC ŠILJ, Zagrebačka industrija 1935. - 1939.

${ }^{22}$ KOLAR DIMITRIJEVIĆ, „Zagrebačke tvornice svile”, 133. 
novih vlasti da se težište gospodarstva s poljoprivrede prebaci na industriju, a društvena uloga seljaštva na „radničku klasu”. ${ }^{23}$ Kao i u međuraću, tekstilna industrija zapošljavala je velik broj niskokvalificirane ženske radne snage iz grada, okolice i nerazvijenih ruralnih područja. ${ }^{24}$ Primjer takve radnice je Zora Knežić, trinaest puta proglašena udarnicom i odlikovana Ordenom rada, o kojoj je detaljnu reportažu objavio tjednik Globus 1963. godine. Ona je samo jedna od tisuća žena koje su provele život u tekstilnoj industriji. Zora je u tekstilnu tvornicu došla 1933. kao trinaestogodišnjakinja iz siromašne zagorske obitelji s petero djece. Jedno vrijeme bila je zaposlena i u tvornici Ivančica, koja je u kontinuitetu radila tijekom Drugoga svjetskog rata, u kojoj se zbog loših socijalnih uvjeta pridružila radničkom pokretu. Nakon rata radnica Zora Knežić zaposlila se u tvornici Pobjeda, a potom od 1963. u Zagrebačkoj industriji svile kao kontrolorka robe. ${ }^{25}$

Radi povećanja zaposlenosti, što je sredinom 60-ih bilo goruće ekonomsko i društveno pitanje, kao i radi sprječavanja ekonomske migracije, ali i odljeva ruralnoga stanovništva, uz centralne tvornice u Zagrebu otvoren je niz manjih pogona u nerazvijenim krajevima Hrvatske. ${ }^{26}$ Tako je npr. tekstilna industrija Pobjeda otvorila u Virju pogon specijaliziran za proizvodnju kord-samta. ${ }^{27}$

Ženska radna snaga većinom je bila niskoobrazovana, stoga je bilo potrebno strukturirati školsko obrazovanje za potrebe rastuće tekstilne industrije. Iz tiska je očito da su postojala dva načina stjecanja stručne kvalifikacije u tekstilnoj industriji. Jedan je bio preko škole učenika u privredi, a drugi školovanje uz rad u nekom od tekstilnih centara. ${ }^{28}$ Prvi tekstilni centar osnovan je 1961. u Zagrebu na temelju odluke Radničkoga savjeta tvornice Pobjeda, a kao suosnivači pridružilo se još devet zagrebačkih tekstilnih poduzeća i Narodni odbor općine Črnomerec. Tim činom osuvremenjeno je i omogućeno sveobu-

23 PAVIŠIĆ, Spomenica desetgodišnjice osnutka poduzeća, 23, 26. O oduzimanju poduzeća, zakonu o nacionalizaciji privatnih i privrednih poduzeća iz 1946. vidi: RADELIĆ, Hrvatska u Jugoslaviji 1945. - 1991., 177-187 (184). O agrarnoj reformi i politici vidi: Isto, 187-198.

${ }_{24}$ ŠIMONČIĆ-BOBETKO, „Razvoj tekstilne industrije u Hrvatskoj”, 103.

25 M. VLADIĆ, „Tekstil se tada prodavao na tačkice”, Globus (Zagreb), 10. 3. 1963., 9.

26 RADELIĆ, Hrvatska u Jugoslaviji 1945. - 1991., 212.

27 J. Mć., „Nova tekstilna tvornica u Virju”, Privredni vjesnik (Zagreb), 29. 11. 1965., 5.

28 U. ŠOŠKIĆ, „Osposobljavanje stručnjaka za potrebe tekstilne industrije”, Vjesnik u srijedu (Zagreb), 31. 3. 1965. Škole za učenike u privredi osposobljavale su kvalificirane radnike za proizvodnju kudjeljinih i drugih biljnih vlakana, prediva i tkanina od lana, kudjelje i jute, pamučnoga prediva i tkanina, vunenoga prediva i tkanina od prirodne i umjetne svile, za proizvodnju konfekcije, trikotaže itd. Osnovna zanimanja bila su: predioničar kudjelje, pamuka, vune i svile, tkalja apreter tkanina, bojadiser, tekstilni štampar, pletač, konfekcionar odjeće, rublja ili trikotaže, užar. U školu su se mogli upisati oni koji su sklopili ugovor o izučavanju zanimanja s nekim poduzećem ili zanatskom radnjom. Tekstilni i konfekcijski centri imali su četiri smjera: prelački, tkalački, pletački i kemijski. U njima je nastava trajala dvije godine, nakon čega polaznici postaju kvalificirani radnici tekstilne industrije. Ako je želio napredovati u struci, radnik je mogao unutar tekstilnoga centra pohađati nastavu dvije godine da bi postao pogonski tehničar; postojala je mogućnost upisa u višu tekstilnu školu, kao i prijelaza na drugi stupanj tehnološkoga fakulteta. 
hvatno obrazovanje tekstilnih radnika na području cijele Hrvatske. U okviru tekstilnoga školskog centra školske godine 1970./71. djelovale su tri škole na području Hrvatske za srednje obrazovanje s dvjestotinjak učenika u četrdeset razrednih odjela, od kojih polovica izvan Zagreba. ${ }^{29}$

\section{Razdoblje od 1945. do 1959. godine}

Od 1945. do 1959. tekstilna industrija u Federativnoj Narodnoj Republici Jugoslaviji (FNRJ) prošla je dvije razvojne faze. Između 1945. i 1951. podržavljene su, obnavljane i modernizirane postojeće tvornice da bi se osposobile za planiranu plansku proizvodnju. Prvi proizvodni planovi tekstilne industrije FNRJ te prvi propisi i standardizacija pojedinih vrsta pamučnih i vunenih tkanina postavljeni su 1947. godine. Organizirana trgovinska mreža na malo nije vršila pritisak na industriju radi proširenja proizvodnoga programa jer su se svi proizvodi zbog nedostatka tekstila mogli rasprodati. Na kraju toga prvoga petogodišnjeg razdoblja tržište potražuje raznolikiju i kvalitetniju ponudu tekstila. Od 1952. prelazi se sa strogo planirane proizvodnje na sustav slobodnijega planiranja i formiranja cijena. Do kraja 50-ih godina, unatoč naslijeđenim, zastarjelim strojevima, postojeća je tekstilna industrija, uz minimalnu rekonstrukciju i modernizaciju tvorničkih pogona, svojim proizvodima uspjela parirati uvoznom tekstilu. ${ }^{30} \mathrm{Da}$ bi se osuvremenilo tekstilnu industriju, paralelno se razmišljalo i o izgradnji domaćih tvornica za proizvodnju tekstilnih strojeva. Tako npr. 1959. Tekstilstroj proizvodi automatske stanove za tkanje pamučnih i laganih vunenih tkanina, a tvornica Ventilator strojeve za sušenje vune. ${ }^{31} \mathrm{U}$ Zagrebu su krajem 50 -ih metražu u većoj mjeri proizvodili TVORPAM, ZIS, Pobjeda i Industrija vunenih tkanina Zora.

U tom je razdoblju u Zagrebu u trgovini tekstilom prednjačilo poduzeće Tekstilpromet. ${ }^{32}$ Pod tim imenom osnovano je 1949. kao sljednik poduzeća iz prijašnjih godina. ${ }^{33}$ Poduzeće je poslovalo $s$ tkaninama od različitih siro-

${ }^{29}$ U Zagrebu je prije djelovala tek jedna tekstilna škola, Srednja tekstilna tehnička škola osnovana 1937./38. godine. Novoosnovanom centru pridružila su se tekstilna poduzeća s područja Hrvatske i Bosne. Vidi: A. K., „Deset godina tekstilnog školstva u Zagrebu”, 1036-1038.

30 PAVIŠIĆ, Spomenica desetgodišnjice osnutka poduzeća, 23.

31 A. M., „Izgradnja naših novih tekstilnih tvornica”, Privredni vjesnik, 14. 3. 1959., 1.

32 Uz Tekstilpromet, važnu ulogu u distribuciji proizvoda tekstilne industrije imalo je i poduzeće Tekstil import-export iz Zagreba, Šoštarićeva ulica 10. Poduzeće je, prema oglašavanju svoje ponude, uvozilo pamuk, vunu, celvlakna, rajon i ostale tekstilne sirovine, poluproizvode i gotove proizvode, a izvozilo pamučne tkanine, celtkanine, sirove, bojene, štampane i sve ostale proizvode tekstilne industrije. Tekstil, 7/1959., 2; Privredni vjesnik, 14. 9. 1968., 4.

33 Tijekom Narodnooslobodilačke borbe na oslobođenom teritoriju osnovana su prva veletrgovinska poduzeća, Glavnoprod (Slunj, 1944.) i Dop. Glavnoprod se bavio distribucijom industrijskih proizvoda raznih struka, a Dop distribucijom prehrambenih proizvoda. Godine 1946. u Zagrebu se osniva Tekstilno trgovačko poduzeće, specijalizirano za promet tekstilom na veliko, koje je svoje centre imalo u većim gradovima. Njegov rad trajao je do 1948., kada se cijelo poslovanje i osnovna sredstva prebacuju u poduzeće Stoteks kao stovarište Glavne direkcije za tekstilnu industriju u Beogradu. To poduzeće obavljalo je raspodjelu tekstilnih 
vina, konfekcijom, svilenom, pamučnom i vunenom trikotažom, čarapama, vezivom, sagovima i drugim tekstilnim proizvodima. S dobrim poslovnim vezama s proizvođačima, kao i rasprostranjenom trgovačkom mrežom u svim jugoslavenskim republikama, poduzeće se etabliralo kao jedno od vodećih u poslovanju tekstilom. Već 1959. Tekstilpromet posluje s četiri inozemne kompanije: njemačkima Leopold Schoeller \& Söhne iz Dürena, Felina iz Mannheima, Nino iz Nordhorna i austrijskom Pottensteiner Tuchfabrik iz Beča. ${ }^{34}$

$\mathrm{Na}$ tržištu su zastupljeni prirodni materijali (pamuk, lan i svila), a pojavljuju se i umjetni (dralon, diolen), koji se ne gužvaju, lagani su i lako se održavaju. ${ }^{35}$ Tekstilna industrija i konfekcija prezentiraju se na mnogobrojnim sajmovima, od kojih su najvažniji Ljubljanski, Beogradski i Zagrebački (vele)sajam. Običavalo se proizvode tekstilne industrije izlagati u zasebnom paviljonu. Za domaće su tekstilne proizvode potrošači već 1959. utvrdili da su izvrsni i na razini europske proizvodnje, a neki su proizvodi, osobito vunene tkanine, bili ocijenjeni čak i boljima od europskoga prosjeka, pa su se u trgovinama mogle kupiti tkanine visoke kakvoće za mušku odjeću: kammgarni, ${ }^{36}$ streihgarni ${ }^{37}$ i tweedovi. ${ }^{38}$ Žene su, suprotno muškarcima, veću pozornost posvećivale uzorcima i bojama tkanina, a kakvoća im je bila manje važna. ${ }^{39} \mathrm{Ubr}$ zo nakon otvaranja samoposluge u Ivancu kraj Varaždina $1956 .{ }^{40}$ pojavljuju se trgovine za prodaju metraže, koje funkcioniraju na principu samoposluživanja, gdje svatko može uzeti balu, opipavati i razgledavati tkaninu. ${ }^{41}$ Trgovinsko poduzeće Robni magazin organiziralo je 1950. radi širenja trgovačke mreže i poboljšanja ponude dvije pokretne prodavaonice: jednu na području Posavine, a drugu na području Zagorja. Nudile su i prodavale široku lepezu svih vrsta tekstilne robe da bi olakšale opskrbu potrošača udaljenih od većih gradova i industrijskih centara. Cjenovno su bile na razini zagrebačkoga tržišta. ${ }^{42}$

proizvoda do 1949., kada poslovanje preuzima Tekstilpromet. PAVIŠIĆ, Spomenica desetgodišnjice osnutka poduzeća, 2.

${ }_{34}$ Isto, 103, 130. Povodom desete godišnjice osnutka Tekstilprometa u Privrednom vjesniku objavljen je intervju s direktorom Brankom Egićem o osnutku poduzeća te o prihodu i produktivnosti rada. „Opskrba tržišta tekstilom: Deset godina uspješnog rada poduzeća Tekstilpromet", Privredni vjesnik, 12. 12. 1959., 1, 6.

35 „Leksikon Kroz modne žurnale”, Svijet (Zagreb), lipanj 1958.

36 Kamgarn (njem. Kammgarn), čvrsta vunena tkanina izrađena češljanjem i predenjem ovčje ili kozje vune za izradu kaputa. Vidi: „Kamgarn”.

37 Strajhgarn (njem. Streichgarn), laka i podatna tkanina od nečešljane vune i mješavine. Vidi: „Streichgarn”.

38 Tvid (engl. tweed, škot. twed), vunena tkanina od grebenane pređe, u kepernom ili platnenom vezu, sitno dezenirana kombiniranjem obojene i neobojene pređe za izradu muških sakoa i ogrtača. Vidi: „Tvid”.

39 „Što mislite o kvaliteti tekstilnih proizvoda?”, Privredni vjesnik, 7. 9. 1959., 3.

40 MILJAN, MIHALJEVIĆ, „Ivanec kao eksperimentalna lokacija jugoslavenske samoposlužne trgovine", 353-385.

${ }^{41}$ „Slobodni izbor robe u tekstilnoj struci”, Privredni vjesnik, 14. 2. 1959., 4.

42 Robni magazin u Zagrebu je imao trgovine na Trgu Republike (današnji Trg bana J. Jelačića), Radićevoj ulici, Ulici socijalističke revolucije (danas Zvonimirova ulica) i u 
Potreba za angažiranjem arhitekata za moderno uređenje trgovina iščitava se već 1959., npr. arhitekt Miroslav Begović uređuje prodavaonicu poduzeća Ukus u Ilici $11 .{ }^{43}$ Prodavaonice tekstila ulaze i u krug zanimanja povjesničara umjetnosti, koji opisuju autorski rukopis pojedinih arhitekata i njihov pristup uređenju interijera. Suvremeno uređena trgovina zahtijevala je nove materijale, „aluminij, staklo, kamene obloge”, koji unutrašnjost čine svijetlom i prozračnom. Istodobno se osobita pozornost počela posvećivati uređenju izloga. ${ }^{44}$

Krajem 50-ih godina primjetna je razlika u pristupu tržištu između proizvođača i trgovaca. Proizvođači tekstila, poput Varteksa, smatrali su da potrošači žele pratiti promjene na tržištu, a suprotno njima, „konzervativni” trgovci smatraju da je tržište zadovoljno „sitnim promjenama, gotovo neprimjetnim razlikama i varijacijama na već prihvaćene i rasprodane tkanine” i naručuju tkanine popularne prije dvije godine. ${ }^{45}$ Već se tada počinje osluškivati puls tržišta i provode se ankete o kakvoći domaćih tekstilnih proizvoda s ciljem poboljšanja i unapređenja proizvodnoga programa. ${ }^{46}$ Tako Privredni vjesnik 1959. objavljuje rezultate ankete provedene na Proljetnom zagrebačkom velesajmu, prema kojoj je bio vidljiv napredak domaće tekstilne industrije u boji, dezenu, kakvoći i načinu izlaganja, a među najbolje ocijenjenim izlagačima bili su Varteks i Nada Dimić. Unatoč svemu, posjetitelji su primjećivali skupoću i stanovita zaostajanja za svjetskom modom pojedinih proizvoda. ${ }^{47}$

Godine 1959. primjetniji su problemi na tržištu tekstila. Proizvodnja tekstila premašivala je potražnju, a istodobno veliki uvoz tkanina postaje konkurencija domaćoj industriji. Stoga su česta tema rasprava u privrednim krugovima bila dva pitanja: nagomilane zalihe robe te poboljšanje plasmana konfekcije i tkanina kreditiranjem kupaca. ${ }^{48}$ Još uvijek se radi o relativno skromnoj potrošnji te se uvode propisi o potrošačkim kreditima koji omogućavaju kupovinu skupljih vunenih tkanina za muška odijela i kapute, za ženske haljine i kapute, gotove odjeće (tekstilna vunena konfekcija), zavjesa i štofova za pokućstvo. Zbog smanjenoga prometa tekstilnih proizvoda došlo je do „znatnog porasta zaliha potrošne tekstilne robe, i to kako kod proizvodnih poduzeća, tako i kod trgovinskih poduzeća i radnja na veliko i malo. Radilo se o zalihama pamučnih i drugih artikala, koji su bili isključeni iz potrošačkih kredita. Zato se pojavila potreba da se u sistemu potrošačkih kredita provede dalja liberalizacija”, što znači kupovanje svih vrsta tekstilnih proizvoda na

zagrebačkoj četvrti Podsused. „Pokretne prodavaonice tekstila”, Privredni vjesnik, 30. 3. 1960., 5.

43 „Nove ideje prodiru u naše prodavaonice”, Privredni vjesnik, 7. 2. 1959., 1.

44 D. VENTURINI, „Tri nova izloga”, 15 dana (Zagreb), 25. 12. 1960., 22-23.

45 „Čiji je ukus neukusan. Tekstil kakav (ne)želimo”, Vjesnik u srijedu, 24. 4. 1959., 1, 4.

46 „Što mislite o kvaliteti tekstilnih proizvoda?”, Privredni vjesnik, 7. 9. 1959., 3.

47 „Što mislite o kvaliteti naših tekstilnih proizvoda”, Privredni vjesnik, 15. 9. 1959., 4.

48 BEZ AUTORA „Potrošački krediti za kupovanje tekstila”, 604; DUDA, Pronađeno blagostanje, 69-70. 
kredit. ${ }^{49}$ Veletrgovci, izbjegavajući poslovni rizik i konzervativno pristupajući odabiru materijala, a zbog straha od stvaranja pretjeranih zaliha, uvoze „već provjerene" tkanine (npr. krep) koje su u inozemstvu izašle iz mode i jeftinije su za prodaju. ${ }^{50} \mathrm{U}$ trgovinama su zabilježene velike količine robe s oznakom „Roba iz uvoza”, što je smatrano svojevrsnom „pljuskom” domaćoj proizvodnji zbog pretpostavke da je slabije kakvoće od uvozne. Osim toga prevladavalo je mišljenje da je metraža za izvoz bila bolje kakvoće od one koja se prodavala u domaćim trgovinama. Trgovci su se na različite načine domišljali kako privući kupce, pa je npr. NaMa, veliko trgovačko poduzeće, na domaću metražu stavila natpise „izvozna roba”. Istodobno je u Zagrebu djelovao Zavod za ispitivanje tkanina, koji je kontrolirao kakvoću domaćega i stranoga tekstila. Na uzorcima uzetim s grčkih i domaćih (Varteks, Zora) tkanina utvrđeno je da su svi bili približno jednake kvalitete i izdržljivosti. Grčke tkanine imale su bolju apreturu ${ }^{51}$, suvremeniji i ljepši dezen, a domaće veći postotak vune. Kao dokaz kakvoće metraže zanimljiva je crtica koju prenosi tjednik Globus o „našem čovjeku koji je na putu u Veneciji kupio izvrsno skrojeno odijelo od odličnog materijala i nosio ga je dvije do tri godine". Nakon toga odnio je odijelo krojaču na "preokretanje” i kada ga je krojač rasparao, na rubovima tkanine pojavila se oznaka ,jedne domaće ugledne tvornice štofova”. ${ }^{52}$ Postoje i suprotni primjeri: zbog loše kakvoće domaće pamučne tkanine, npr. popeli$n^{53}$ za muške košulje, tvornica Kamensko prisiljena ga je uvoziti iz Japana. ${ }^{54}$

Kraj 50-ih godina obilježilo je odobrenje popusta ili bonifikacija ${ }^{55}$, pa se čak našla i kao tema karikature objavljene u Vjesniku u srijedu iz lipnja 1960. (slika 1). Trgovci pregledavaju metražu i telefonski javljaju tvornici: „Opet ste pogriješili: poslali ste nam robu bez griješke!” Najbolje su se u problemima tekstilne metraže snalazili trgovci, prikrivajući greške u tkanju koje je tvornica označavala nitima u boji i tvorničkim oznakama metraže i bonifikacije. Neriješen sustav nagrađivanja u trgovinskoj mreži doveo je do učestale prakse zatajivanja bonifikacije, što autor teksta sažima i formulira kao „prosto pra-

49 P. N., „Nabava tekstila i kredit. Sazreli su uvjeti da se potrošačkim kreditima mogu nabavljati sve vrste tekstilnih proizvoda”, Privredni vjesnik, 31. 12. 1959., 2; „Potrošački krediti za kupovanje tekstila", 604.

50 Krep (franc. crêpe, prema lat. crispus: kovrčav), tkanina zrnate, smežurane ili naborane površine. Vidi: „Krep”.

51 Apretura (franc. apprêter: pripraviti), završni postupci oplemenjivanja tekstilnih materijala, također sredstva za oplemenjivanje kojima se materijalima daju konačna svojstva i izgled. Vidi: „Apretura”.

52 Sead SARAČEVIĆ, „Jedan i jedan nisu uvijek dva”, Globus, 30. 10. 1960., 19-23.

53 Popelin (franc. popeline, engl. poplin), tkanina od fine, čiste ili miješane pamučne pređe tkana u platnenom vezu s fino strukturiranom površinom; osobito je cijenjen pamučni mercerizirani pamuk za izradu košulja i bluza. Vidi: „Popelin”.

54 F. Z., „Što izlažu proizvođači tekstila / kroz velesajamske paviljone”, Privredni vjesnik, 7. 5. 1960., 3 .

55 Bonifikacija (franc. bonification), odobrenje popusta u apsolutnom ili relativnom iznosu od vrijednosti robe ili usluge po sporazumu kupca ili prodavatelja zbog utvrđene manjkavosti kvalitete, kvantitete i izgleda roba ili usluga. Vidi: „Bonifikacija”. 
vilo trojno: niska primanja + palac + bonifikacija = zadovoljstvo na radu", što bi značilo da su se niska primanja mogla kompenzirati varanjem kupaca u izmjeri metraže i prešućivanjem odobrenja popusta (slika 2). Takve, kupcima neprimjetne, prakse omogućavale su trgovcima veću zaradu. ${ }^{56}$

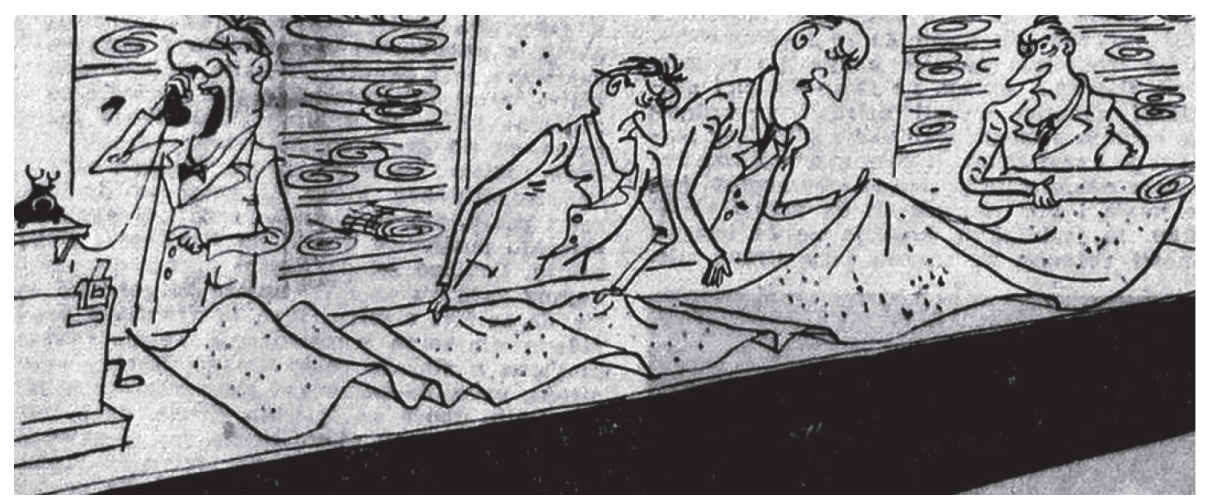

Slika 1. Karikatura vezana uz tekst o bonifikaciji (Vjesnik u srijedu, 1. 6. 1960., 4)

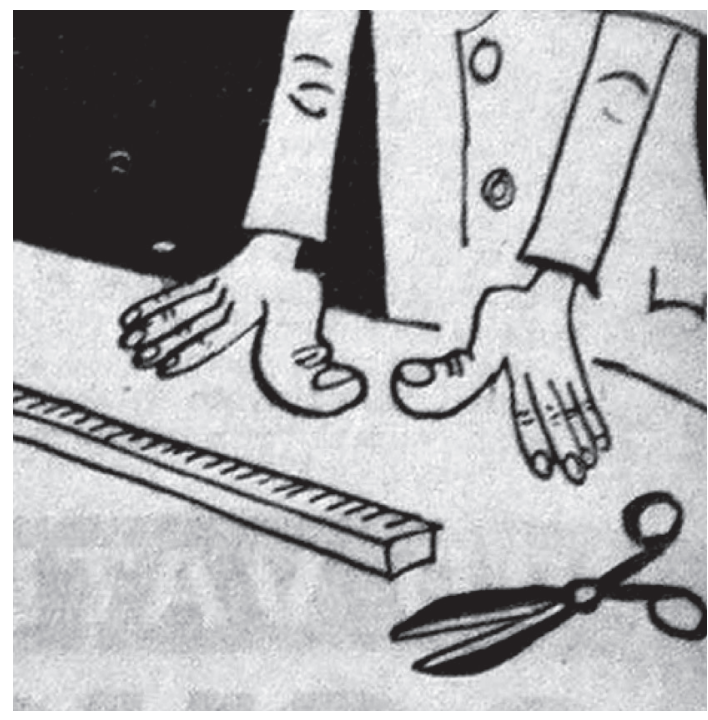

Slika 2. Karikatura vezana uz tekst o bonifikaciji (Vjesnik u srijedu, 1. 6. 1960., 4)

Svi navedeni problemi i nastojanja tadašnje tekstilne industrije vidljivi su na primjeru ZIS-a. Još potkraj 50 -ih imao je loš strojni park i organizaciju posla, a proizvodi (podstave, rublje) bili su neatraktivni i loše kakvoće. Preko engleskih, talijanskih, francuskih i njemačkih modnih listova tvornica

56 Nikola POLAK, „VUS-ov dosje: 'U dobar čas': Spornih 5 centimetara”, Vjesnik u srijedu, 1. 6. 1960., 4 . 
je pokušavala pratiti suvremene trendove. Proširuju proizvodni program na svilene tkanine modernih uzoraka za dnevne i večernje haljine, tiskane svile, modni pike sa pliseom, prugaste svile od bojenog prediva, modne taftove, najlon, perlon i prvi put uvode novi proizvod: „materijal za steznike domaće proizvodnje". U pripremi su imali proizvodnju težega svilenog brokata za plesne haljine, ukrasne prekrivače i svilu za kravate. Robu uspješno prodaju i nemaju zaliha na skladištu. Ali, unatoč svemu, još uvijek su imali problema s postrojenjem za doradu tkanina. ${ }^{57}$

Krajem 50-ih pokazala se potreba za sudjelovanjem umjetnika u industrijskom oblikovanju tekstila. Suradnja je ostvarena, a u tisku se spominju dizajnerice tekstila Desa Tomić-Đurović, koja je radila za ZIS i TVORPAM, ${ }^{58}$ Marija Kalentić radi za ZIS, TVORPAM i Vunteks, ${ }^{59}$ Vera Verica Antunović za Varaždinsku industriju svile (VIS) i ZIS ${ }^{60}$ i Jagoda Buić za TVORPAM. ${ }^{61}$

Očito je da se industrija nakon Drugoga svjetskog rata temeljila na onoj postojećoj i da se u proizvodnju ušlo sa zastarjelom tehnologijom. Paralelno s proizvodnjom za gradsko tržište tvornica Naprijed imala je poseban pogon za proizvodnju pamučnih tkanina namijenjenih seoskim potrošačima. ${ }^{62}$ Izrada materijala za seosko tržište zadržala se i ranih 70-ih godina, kada ponovno postaju popularni „zaboravljeni materijali kao slama i grube 'seljačke' tkanine". ${ }^{63}$ Radi se o nastavku proizvodnje iz međuraća za potrebe sela, koje napušta ručnu proizvodnju domaćega tkanja i postaje jedan od većih potrošača tvorničkoga tekstila. ${ }^{64}$

Pedesetih godina s poratne racionirane privrede prešlo se na tržišnu uz postupni razvoj mreže specijaliziranih trgovina i povezivanje s međunarodnim tržištem na principima uvoza i izvoza. Iako još postoje brojna ograničenja i slabosti poput državnoga planiranja i nedostatka kvalitetnije robe, ipak se primjećuje prihvaćanje modnih trendova zapadnih zemalja u kakvoći tkanina i dezenu.

\section{Razdoblje od 1959. do 1965. godine}

Probleme koji su se pokazali potkraj 50-ih pokušalo se prevladati reformama iz prve polovine 60-ih. Najprije je pripremljena i u ožujku 1961. pokrenuta gospodarska reforma, poznata pod imenom „mala privredna reforma”,

\footnotetext{
57 J. M., „Noviteti domaće industrije: Kroz Paviljon 6”, Privredni vjesnik, 9. 4. 1959., 2.

58 POPOVIĆ, „Odsek za savremenu primenjenu umetnost”.

59 Vidi: „Kalentić, Marija”.

60 BRKIĆ-MILINKOVIĆ, „Nije dočekala Četvrtak...: Vera Antunović (1938. - 2008.)”.

${ }_{61}$ Dokumentacija Muzeja za umjetnost i obrt, Inventarna knjiga br. 6, MUO 10648.

62 Ante GAVRANOVIĆ, „Ekonomska nužnost ili trenutačna potreba?: Problemi u radu industrijskih prodavaonica”, Privredni vjesnik, 1. 1. 1959., 9.

63 „Tekstil: U korak s modom”, Privredni vjesnik, 18. 4. 1972., 2.

64 Vidi u: ŠIMONČIĆ-BOBETKO, „Razvoj tekstilne industrije u Hrvatskoj”.

65 MIHALJEVIĆ, „Liberalizacija 1960-ih - podloga Hrvatskog proljeća”, 263-277.
} 
s idejom o većoj samostalnosti poduzeća, ali središnja vlast zadržava nadzor nad cijenama, investicijskim fondovima i trgovinom s inozemstvom. Najvažnija promjena u odnosu na prijašnje razdoblje pokušaj je da se poduzećima dopuste veća prava u raspodjeli dohotka, potrošnje i akumulacije. Zbog toga su neka poduzeća trošila više na plaće, a manje na akumulaciju. Istodobno pada proizvodnja zbog pomanjkanja sirovina i raste potrošnja u odnosu na proizvodnju. Sve to uvjetuje gospodarsku stagnaciju i, prvi put u socijalizmu, događa se veće otpuštanje radnika. Reforma je zbog neuspjeha zaustavljena krajem 1961. godine. ${ }^{66}$

Od 1963. do 1965. pripremana je gospodarska i društvena reforma koja je trebala omogućiti veću ulogu poduzeća, općina i republika. U srpnju 1965. započela je nova reforma s petogodišnjim planom čija je provedba trebala početi 1966., s tridesetak novih zakona. Cilj te reforme bio je poštovanje ekonomskih kategorija i jače uključivanje u svjetsku ekonomiju. Reformom se pokušalo osigurati legalni okvir za „tržišni socijalizam”, kojim se uvodio kapitalistički način poslovanja bez privatnoga vlasništva. ${ }^{67}$ Od 1965 . do 1967. počinje pad stope rasta industrijske proizvodnje kakav nije zabilježen od 1952. godine: smanjuje se kreditiranje, poljoprivreda stagnira, pada stopa zapošljavanja. Mnoga poduzeća nisu mogla izdržati imperativ rasta proizvodnje jer svoju robu nisu mogla plasirati na strana tržišta, a istodobno je rastao pritisak uvezene robe. Da se ne bi smanjivale plaće, obustavljeno je zapošljavanje, a uskoro je uslijedilo i otpuštanje radnika. Od 1964. do 1967. broj zaposlenih je u padu, a nezaposlenost je prihvaćena kao pratilja privredne reforme iz 1965. godine. Veliki val gospodarske emigracije krenuo je u zapadnu Europu, najviše u Saveznu Republiku Njemačku. ${ }^{68}$ Tekstilna je industrija 1967. i dalje suočena s velikim kadrovskim problemima: u izravnoj proizvodnji $4 \%$ radnika imalo je visoku kvalifikaciju, a $40 \%$ bilo je bez kvalifikacije. Tekstilni radnici, radnici u predionicama i tkaonicama pamuka ostvarivali su za petinu niži osobni dohodak od radnika u ostalim industrijama. Radnici u predionicama i tkaonicama vune imali su prihod niži za trećinu, a oni u kudjeljarama i lanarama ostvarivali su prihod gotovo upola manji od prosječne zarade u industriji. ${ }^{69}$

Tekstilna metražna industrija prije i u vrijeme velike privredne reforme posluje u kontekstu naslijeđenih problema iz prethodnoga razdoblja. Unatoč govoru o tržišnoj orijentaciji, očita je dominantna uloga države. To se vidi u međudržavnim trgovinskim ugovorima, zbog kojih je čak zakonski nametnut obvezan udio proizvodnje za izvoz. I dalje je prisutan problem uvoza pamučnih tkanina za domaće tržište uvjetovan uvozom nekvalitetnih sirovina, npr. pamuka, što je rezultiralo proizvodnjom nekvalitetnih pamučnih tkanina,

66 RADELIĆ, Hrvatska u Jugoslaviji 1945. - 1991., 331.

67 Isto, 333.

68 Isto, 336.

69 „Prosperitet je daleko, da li i nedostižan?”, Privredni vjesnik, 5. 3. 1970., 6. 
nekonkurentnih na domaćem i europskom tržištu. Istodobno su radi regulacije problema u tekstilnoj proizvodnji 1963. doneseni propisi prema kojima tekstilne tvornice moraju izvoziti $30 \%$ proizvodnje. ${ }^{70}$ Primjer da su tvornice težile ispuniti zakonske odredbe jest podatak da zagrebački TVORPAM planira 1963. proizvesti oko 16 milijuna metara različitih tkanina, što znači da će izvoziti gotovo $22 \%$ svoje ukupne proizvodnje. ${ }^{71}$ Iduće, 1964 . godine tekstilna industrija u Jugoslaviji bila je na 4. mjestu po izvozu, iza metalurgije, metalne i prehrambene industrije. $^{72}$

Početkom 60-ih proizvođači metraže bili su uglavnom usmjereni na proizvodnju za potrebe konfekcije, industrijske, serijske izrade odjeće u standardnim veličinama. ${ }^{73}$ Kao što je to pokazalo jedno drugo istraživanje, najveći potrošači bile su šnajderice, ne samo vlasnice krojačkih salona nego i mnoge bezimene s obzirom na to da su šivaći strojevi domaće tvornice Bagat, kao i uvozni, osobito Singer, postali dostupniji. ${ }^{74}$ Drugi najveći korisnici tekstila u metraži bili su zagrebački krojački/modni saloni, primjerice Žuži Jelinek ${ }^{75}$ i Tilde Stepinski ${ }^{76}$, i krojačke zadruge Đuro Bermanec (muška konfekcija), Trešnjevka (ženska konfekcija), Zanatska radnja Ponos (dječja konfekcija) ${ }^{77}$, Ženska moda (ženska konfekcija) ${ }^{78}$, Ukus-Trajnost (surađivali su s tvornicom Naprijed). ${ }^{79}$

Problem favoriziranja stranoga spram domaćega tekstila stalno postoji na tržištu. Radije se kupuje skuplji strani tekstil lošije kakvoće od domaćega, pri čemu se lošija kakvoća često utvrđivala tek u krojačnicama. Takav način razmišljanja domaćih kupaca pogodovao je razvoju „crnoga tržišta tkaninama”, koje je 1964., kao novinar Vjesnika u srijedu, zabilježio poznati hrvatski književnik Ratko Zvrko. Preprodavači su jeftino kupovali loše tkanine u ino-

70 Drago TOVIĆ, „Zamršeno klupko tekstilnog izvoza: Dok jedni rade i knjiže gubitke, drugi ubiru procente", Vjesnik u srijedu, 19. 6. 1963., 4.

71 Vidi: „Zagrebška tekstilna tovarna TVORPAM”.

72 Š., „Vanjska trgovina u 1964.”, Privredni vjesnik, 27. 1. 1965., 1.

73 J. MILIČIĆ, „Dalji napredak konfekcije”, Privredni vjesnik, 16. 4. 1961., 2.

74 PETROVIĆ LEŠ, KLOBUČAR, „Nähen als informelle Ökonomie im Zagreb der 1960er Jahre".

75 Žuži Jelinek ostvarila je suradnju s tvornicom Nada Dimić 1968. godine. Uvjet za suradnju bio je da Nada Dimić osigura materijale u točno određenim bojama, a Žuži Jelinek od njih je oblikovala najsuvremenije, jednostavne i elegantne modele za proljetnu sezonu. Dio tih modela bio je izložen u njezinu salonu na tadašnjem Trgu Republike 4/II, a drugi dio otkupila je tvornica. Zanimljivo je da su te modele kupci mogli nabaviti već dvadesetak dana nakon predstavljanja, i to samo u tvorničkom dućanu „Boutique” u Draškovićevoj ulici 13. Ta je suradnja, za razliku od prijašnje prakse, kada je moda u dućane dolazila sa zakašnjenjem od godinu ili dvije, u to doba bila isticana kao primjer pravodobnoga plasmana ženske odjeće „skrojene po najnovijoj pariškoj modi za sezonu proljeće 1968”. „Žuži Jelinek kreira za vas”, Vjesnik u srijedu, 27. 3. 1968., 18; ARČABIĆ, Žuži Jelinek: ambasador mode, 8, 65-67, 97.

76 „Stotinu uzoraka 'made in Jugoslavia”, Globus, 18. 9. 1960., 40-41.

77 J. MILIČIĆ, „Dalji napredak konfekcije”, Privredni vjesnik, 16. 4. 1961., 3.

78 m. m., „Zvonko Rovnih - Poslovođa prodavaonice 'Zagrebtekstila' u Zagrebu”, Privredni vjesnik, 6. 4. 1966., 8 .

79 M. M., „Novi pogon za ženske ogrtače”, Privredni vjesnik, 7. 4. 1965. 
zemstvu i razvili čitavu trgovinu tkaninama. Naivnim kupcima preprodavali su ih pod izlikom da su dobili tkanine kao „poklon iz inozemstva” koji im trenutačno nije potreban. ${ }^{80}$

Sredinom 60-ih godina tekstilna industrija suočena je s problemima nabave sirovina, repromaterijala i rezervnih dijelova. To doba karakterizira deficit u sintetičkim vlaknima, stoga je u pitanje dovedeno ne samo praćenje modnih trendova, koji uvode sve više umjetnih materijala u izradu svih vrsta odjeće, nego i proizvodnja „obične” odjeće: muških, ženskih i dječjih čarapa i drugih trikotažnih proizvoda. Problemi postoje i u uvozno-izvoznoj politici, a odnose se na odobravanje predujma i problem s devizama. ${ }^{81}$ Do olakšanja u tekstilnoj industriji došlo je otvaranjem novih tržišta u nesvrstanim zemljama, pa se uspijevala ispuniti kvota za izvoz. U zemlje nesvrstanoga bloka, Libiju, Indiju, Nigeriju i Zambiju, izvozile su se različite vrste tekstila, od metraže do poluproizvoda te gotove konfekcije, pozamanterije, putničkih kofera, torbi, ćilima, krojačkoga alata i tekstilnih strojeva. ${ }^{82}$

Unatoč svim navedenim problemima, tekstilna industrija u Zagrebu 1965. zauzimala je prvo mjesto po ukupnom prihodu i broju zaposlenih, a po neto proizvodu bila je odmah iza metalne industrije. ${ }^{83}$ Primjer jedne takve uspješne zagrebačke tekstilne tvornice bila je Pobjeda, koja je 1966., u vrijeme početka privredne reforme, bila orijentirana na modernizaciju i rekonstrukciju te je izvozila veći dio proizvodnoga programa jer: „Robu prodaje jedino kvaliteta, niska cijena i poštivanje rokova." ${ }^{84} \mathrm{U}$ to je vrijeme tvornica ulagala $\mathrm{u}$ školovanje i zapošljavala kvalificirane radnike, od kojih je bilo 70 \% žena, te je pazila na radnu disciplinu. Tvornica je bila jedini jugoslavenski proizvođač kord-samta ${ }^{85}$ u pet različitih kakvoća prema namjeni, od laganih do teških. Ujedno je i najveći proizvođač gradl jacquarda ${ }^{86}$ i tiskanih tkanina od pamučnoga i umjetnoga prediva. Pobjeda proizvodi dvije grupe proizvoda: tkanine izrađene od pređe u mješavini dralon-cupram (za koje se navodi da su uspjele

80 Ratko ZVRKO, „Štof za naivne”, Vjesnik u srijedu, 6. 5. 1964., 1.

81 Š., „Teškoće tekstilne industrije”, Privredni vjesnik, 27. 1. 1965., 1.

82 „Izvoz - uvoz / Konjuktura i tržište”, Privredni vjesnik, 13. 1. 1965., 1; „Izvoz - uvoz /

Konjuktura i tržište", Privredni vjesnik, 16. 1. 1965., 2; RADELIĆ, Hrvatska u Jugoslaviji 1945. - 1991., 283.

83 (m.m.), „Poslovna grupacija tekstilaca: Zagrebačka tekstilna industrija u novim privrednim uvjetima”, Privredni vjesnik, 13. 11. 1965., 2.

${ }^{84}$ „Reforma u ogledalu”, Svijet, 15. 12. 1966., 4.

85 Samt, vrsta tkanine od pamučnih i vunenih prediva s uzdužnim rebrima baršunastoga lica. Kord-samt baršun ili čvrsta pamučna tkanina s prugastim ili vrpčastim uzorkom, pogodna za mušku, žensku i dječju odjeću. Vidi: „Körd-samt”.

86 Gradl (njem. Gradel), čvrsta pamučna tkanina u kepernom vezu ili ribljem keperu. Bijela tkanina najčešći je materijal za laboratorijske kute, pregače i posteljinu, prugasta za pidžame, a tamno obojena za radna odijela. Vidi: „Gradl”. Žakard (franc.), vrsta dezeniranoga tkanja izrađena na posebnim tkalačkim strojevima s izbušenim karticama koje je osmislio francuski tehničar i tkalac Joseph Marie Jacquard krajem XVIII. stoljeća. Tkanjem se dobivaju bogato uzorkovane tkanine, posebno dekorativne za namještaj, kravate, stolne i podne prostirke. Vidi: „Jacquard, Joseph Marie”. 
u dezenima i prikladne za izradu haljina, kostima, košulja i hlača) i mješavine sintetičkih tkanina: trevira, terilen, terilenka i diolen s egipatskim dugovlaknastim češljanim pamukom. ${ }^{87}$ Odjeća od tih materijala lagana je i izdržljiva, lako se održava, postojanih je boja, može se plisirati te dugo zadržava oblik. Tvornica se posebno specijalizirala za proizvodnju tkanina za šivanje „gornjih odjevnih predmeta" poput balonera, kaputa i sakoa. Za ženske i muške ogrtače, vjetrovke, kupaće kostime, šešire i drugo koristi se tkanina izrađena od $100 \%$ dugovlaknastoga češljanoga egipatskog pamuka, bojena samo indanthren bojama, ${ }^{88}$ dodatno vodootporna, impregnirana i s minimalnim skupljanjem. Osim na tržištu dobro poznatih tkanina od mješavine „dralona s cupramom", svoju su proizvodnju 1968. obogatili proizvodnjom tkanina od sintetičkih vlakana, $100 \%$ dralona, u najmodernijim dezenima za dekoracije (zastori, stolnjaci) stanova i ugostiteljskih objekata. Istodobno su proizvodili nove tipove tkanina vizualno obogaćene efektima različitih načina tkanja. Vrsta samta, velveton, ${ }^{89}$ obogaćena je novom paletom boja. ${ }^{90}$ Trendovski proizvod i dalje je bio kord-samt suvremenih dezena, osobito sitni rez tkanine pogodan za izradu haljina, kostima, dječje odjeće i hlača. Kord-samt se izvozio u Sjedinjene Američke Države, Aziju, Afriku, zapadnoeuropske, skandinavske i zemlje istočnoga bloka. ${ }^{91}$ Prema tadašnjim poznavateljima mode, kord-samt je bio zanimljiv za mlade i za žene, a reklamiran je kao najnoviji modni krik 1968., pogodan za šivanje tada popularne maksi suknje. ${ }^{92}$ Važan novitet u Pobjedinu proizvodnom programu 1971. bila je proizvodnja ,jeans tkanina u više boja". ${ }^{93}$ Unatoč teškoj situaciji u tekstilnoj industriji početkom 70 -ih, tvornica Pobjeda ostvarivala je dobre poslovne rezultate. Na Zagrebačkom velesajmu 1971. dogovorila je svoju proizvodnju samta dvije godine unaprijed s kupcima iz Sjedinjenih Američkih Država, Švedske i drugih zapadnih zemalja. $^{94}$

Prateći Zagrebački velesajam, novinarka Magda Weltrusky prikazala je situaciju u tekstilnoj industriji sredinom 60-ih godina. Zaključuje da je do-

87 Trevira, terilen, terilenka i diolen su vrste poliesterskih tkanina.

88 Indantrenske boje su sintetska organska bojila dobivena od derivata antrakinona. Prva takva boja (indantrensko modrilo) nastala je 1901. u njemačkoj kemijskoj kompaniji. Vidi: „Indantrenske boje”; MICHEL, „Century Of Success”. Tvornica Pobjeda dodatno je na konfekcionirane proizvode ušivala oznaku TIP kao jamstvo kakvoće i ekonomičnosti. „TIP Visoka kvaliteta proizvoda postignuta specijalizacijom proizvoda", Privredni vjesnik, 27. 7. 1966., 6.

89 Velveton je vrsta pamučne tkanine koja imitira baršun.

90 Posebno zanimljive boje tkanina su pastelne i žarki tonovi, cijela skala smeđih tonova, oranž, žuta, bijela, crvena i zelena.

91 „U korak s modernim: Kord-samt za mlade - Govori: Direktor 'Pobjede’ Milan Stopić”, Privredni vjesnik, 16. 4. 1968., 4; „Tkanine prema želji kupaca: Pamuk i sintetika na sajmu”, Privredni vjesnik, 14. 9. 1968., 4.

92 „U korak s modernim: Kord-samt za mlade - Govori: potrošač: Slobodanka Jeremić, maneken iz Beograda", Privredni vjesnik, 16. 4. 1968., 4.

93 „9. Magična pošiljka”, Elle - Ona (Ljubljana), 15. 7. 1971.

94 „Tekstilci uspješno”, Privredni vjesnik, 19. 9. 1971., 2. 
maća tekstilna industrija najbolja u proizvodnji teških tkanina, slabija u laganijim i najslabija u tankim svilenim i sličnim tkaninama. Po kakvoći izdvaja ZIS, koji proizvodi brokate koji se približavaju metalu, osobito sjaju aluminija, te su zato vrlo moderni jer tzv. „kozmonautska moda još nije prošla”. Kao važnu novost ističe preslagivanje unutar tekstilne industrije, oblike i načine udruživanja i razdruživanja te utjecaj novonastalih poslovnih odnosa na kakvoću proizvoda. ${ }^{95}$ Naime, usmjeravanje prema tržišnom poslovanju omogućilo je tvornicama tekstila ekonomske poteze poput udruživanja srodnih proizvođača radi jačanja pozicije na tržištu. Udruživanja su se sklapala među zagrebačkim tvornicama, hrvatskim tvornicama, kao i zagrebačkim tvornicama s onima iz drugih republika. Osim u konfekciji, udruživale su se i druge tvornice u skladu s proizvodnim asortimanom. Godine 1965. poduzeća pamučne industrije iz Hrvatske i zapadne Bosne udružila su se u Pamteks

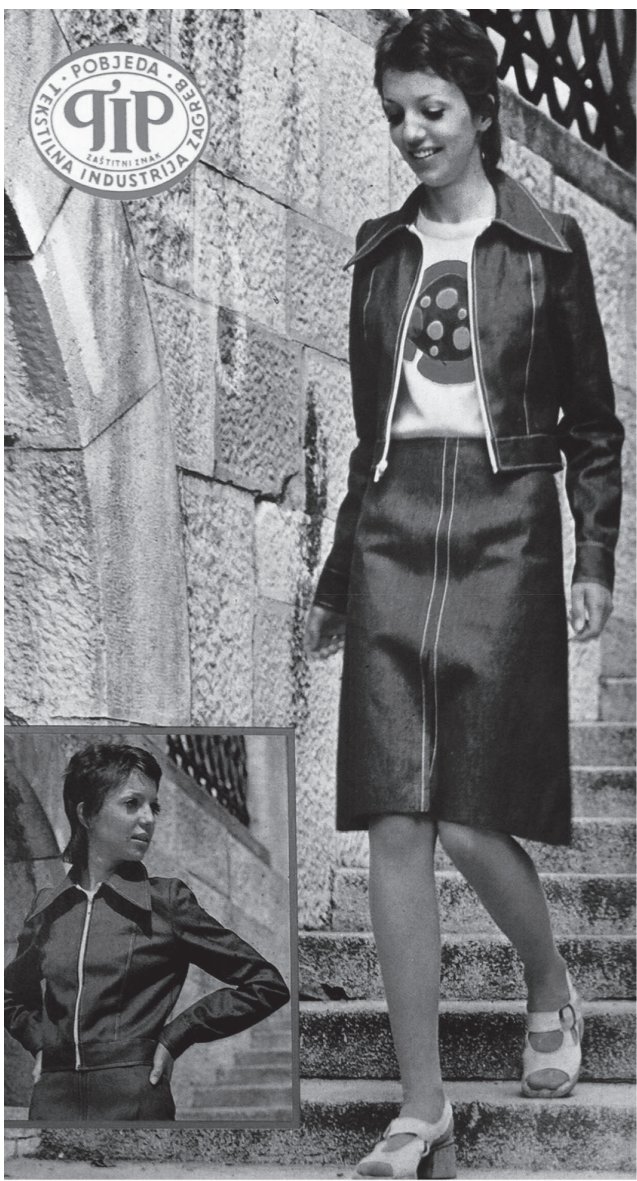

Slika 3. Reklama tvornice Pobjeda: suknja $i$ bluzon od pamučne jeans tkanine (Elle - Ona, 15. 7. 1971.) (Pamučna industrija Pobjeda, TVORPAM, Unitas i Tekstil export-import). ${ }^{96}$ Iste godine TVORPAM se zbog osiguravanja kvalitetne pređe udružuje s Predionicom Zagreb i Predionicom Klanjec u Tekstilni kombinat Zagreb (TKZ). ${ }^{97}$ Politika udruživanja, sve potrebnija zbog pritisaka tržišta, nastavlja se i u idućem razdoblju. Proizvođači tkanina i konfekcije od diolena radi zajedničkih nastupa na sajmovima i revijama organiziraju se od 1967. u klub Diolen. Članovi kluba su: Volnenka,

${ }_{95}$ Magda WELTRUSKY, „Velesajamski tekstilni koktel”, Svijet, 1. 10. 1966., 8-9.

96 J. Mć., „'Pamteks' - novo poslovno udruženje poduzeća pamučne industrije”, Privredni vjesnik, 30. 1. 1965., 1.

97 „Kvalitetniji proizvodi - veća akumulativnost. Tekstilni kombinat Zagreb”, Privredni vjesnik, 14. 5. 1966., 5; V. ŠUBIĆ, „Dosad najveći uspjesi zagrebačkih tekstilaca. Što je pokazala integracija tekstilnih tvornica 'Tvorpam', 'Zagreb' i 'Klanjec”, Privredni vjesnik, 15. 1. 1966., 5 . 
Ljubljana; Tekstilni kombinat Zagreb; Standard konfekcija, Zagreb; Novoteks, Novo Mesto; Svila, Maribor i Kamensko, Zagreb. ${ }^{98}$

Razdoblje od 1965. do 1971. godine

Početkom 70-ih godina tekstilna metražna industrija dostigla je višu razinu, za koju Magda Weltrusky, ocjenjujući proizvodni asortiman nekih tvornica na Beogradskom sajmu, upotrebljava birane riječi: „slapovi metraže vrlo visoke kvalitete”, „ekskluzivni dezen, plemenitost prerade i ljepota cjelokupnog dojma". ${ }^{99}$ Njezini komentari djelomično odgovaraju situaciji u tekstilnoj metražnoj proizvodnji jer se odnose samo na estetsko vrednovanje proizvoda. Takvi pohvalni tekstovi doprinosili su stvaranju pozitivne slike o jugoslavenskoj tekstilnoj proizvodnji iako je stanje bilo suprotno.

U tom razdoblju država prepušta gospodarstvu oblikovanje cijena, po čemu se vidi koliko dugo tržište nije bilo pravo slobodno tržište. Proizvođači tekstila, prediva i tkanina dobili su početkom 1968. dozvolu za slobodno oblikovanje cijena. S druge strane vidljiva je prejaka strana konkurencija, a slaba zaštita države, što će na kraju dovesti do traženja zaštitnih mjera (kontrola uvoza, vezani uvoz-izvoz). Pretpostavljalo se da bi slobodne cijene mogle primorati tekstilce da povedu više računa o kakvoći proizvoda, da počnu proizvoditi „modne ekskluzivitete” te se bolje i brže kroz trgovačku mrežu prilagode ukusu i zahtjevima domaćega i inozemnoga tržišta. ${ }^{100} \mathrm{Na}$ sjednici Savjeta za trgovinu Savezne privredne komore raspravljalo se o utvrđivanju proporcija za raspodjelu globalne devizne kvote za uvoz robe osobne potrošnje u 1968. te je utvrđeno da uvoz tekstilnih proizvoda može činiti $28 \%{ }^{101}$ Unatoč nastojanjima, pojavljuje se nekontrolirani uvoz tekstila, o čemu govori podatak da je u prva četiri mjeseca 1968. uvezeno više od količine koju se planiralo uvesti tijekom cijele godine. Tekstilci su bili zabrinuti činjenicom da uvoznici nisu poštovali osnovne zahtjeve: dopuna asortimana, stimulacija domaće proizvodnje i eventualne intervencije u slučaju visokih cijena. Dapače, ističe se, uz rijetke iznimke, u inozemstvu su nabavljeni proizvodi lošije kvalitete, i to po dampinškim cijenama, ${ }^{102}$ poput čarapa, pamučnih tkanina i popluna. Želja tekstilaca bila je ograničenje uvoza i kontroliranje kakvoće proizvoda. ${ }^{103}$

98 „Proljeće - ljeto u stilu Diolen 68”, Svijet, 22. 5. 1968., 32, 33.

99 Magda WELTRUSKY, „Sajam - više 'svetski' nego domaći: XII Beogradski sajam Moda u svetu", Svijet, 20. 10. 1971., 9.

100 „Tko ide naprijed, sve proda. Pouka s nastupa tekstilne industrije u okviru sajma robe široke potrošnje", Privredni vjesnik, 19. 4. 1968., 2.

101 „Kako, koliko i što uvoziti”, Privredni vjesnik, 20. 6. 1968., 6.

102 Damping je postupak uništenja konkurencije prodajom proizvoda po cijenama koje ne pokrivaju troškove proizvodnje. Vidi: „Dàmping”.

103 „Tekstilci i uvoz”, Privredni vjesnik, 8. 8. 1968., 7. 
Sedamdesete su vrijeme propitivanja situacije u Hrvatskoj unutar Jugoslavije kroz ustavotvorna pitanja, pitanja nacionalne ravnopravnosti, jezika i identiteta te gospodarstva. ${ }^{104}$ Nagomilani gospodarski problemi odražavaju se osobito na tekstilnu industriju, pa tako i na onu u Hrvatskoj i Zagrebu. Privredni vjesnik detaljno opisuje probleme i situaciju u tekstilnoj industriji od sredine 60-ih do početka 70-ih godina. Do 1966. proizvodnja tekstila je rasla, čak i više od cjelokupne industrijske proizvodnje, a krajem 60-ih uočava se problem stagnacije potrošnje, nerazvijene trgovačke mreže i manjak skladišnih prostora. Istodobno na svjetskom tržištu rastu cijene tekstilnih sirovina i pomoćnih sredstava za proizvodnju tekstila. Tekstilna industrija nalazi se u stalnom raskoraku između ekstenzivne industrije koja treba zaposliti veliki broj radne snage, koja je brže napuštala selo i poljoprivredu nego što su se ostvarivale objektivne mogućnosti za zapošljavanje u nepoljoprivrednoj proizvodnji, i s druge strane pokušaja modernizacije. Upravo su to dva osnovna problema: nedostatak sredstava za modernizaciju i prezaposlenost, tj. sve veće korištenje tekstilne industrije kao socijalnoga, a ne ekonomskoga čimbenika. S obzirom na velik broj tvornica na području Jugoslavije ranih 70-ih, od 330 do 400, nije se predviđala gradnja novih, nego primjena nove tehnologije i elektronike. Glavni razlog za modernizaciju postojeće proizvodnje bio je veliki broj zastarjelih strojeva, za koje se pisalo da se takve u drugim zemljama može vidjeti u „tehničkim muzejima”. S druge strane, novi tekstilni pogoni imaju probleme s radnicima zbog nedovoljnoga iskustva u upravljanju novim strojevima. Stagnacija u prodaji, niski priljev novčanih sredstava, zaostajanje u plaćama u ukupnoj industrijskoj proizvodnji kod radnika je izazvalo „apatiju i nezadovoljstvo", besperspektivnost. ${ }^{105}$ Gotovo istim riječima i donekle sličnim podatcima opisano je stanje tekstilne industrije u Jugoslaviji od 1965. do 1969. godine. Niska stopa godišnjega rasta iznosila je 3,3\%, pri čemu je proizvodnja pamučarske pređe porasla sa 92 na 96 milijuna kilograma, vunarske pređe sa 26 na 36 milijuna kilograma, a pamučarskih tkanina sa 410 na 415 milijuna $\mathrm{m}^{2}$. Pamučarski sektor je stagnirao, a počela je rasti proizvodnja čarapa, konfekcije i rublja. Od 1965. do 1969. zalihe su narasle za $96 \%$, što je jasan pokazatelj problema u plasmanu domaće robe.

Drugi problem bilo je, iz političkih razloga, pretjerano zapošljavanje, pa je od 1966. do 1969. broj zaposlenih u jugoslavenskoj tekstilnoj industriji narastao sa 213000 na 224000 . Godine 1968. i dalje se radilo na zastarjelim strojevima otpisanim sa $51 \% .^{106}$

Tekstilna industrija zapošljavala je 1970. godine 230000 radnika, od čega $65 \%$ žena, a dohodak je bio 30 \% ispod prosjeka industrije Jugoslavije. ${ }^{107} \mathrm{U}$

104 RADELIĆ, Hrvatska u Jugoslaviji 1945. - 1991., 379-428.

105 „Tekstilci na vjetrometini. Tekstil u škarama male potrošnje i rastućih troškova”, Privredni vjesnik, 2. 4. 1970., 4; „Tekstilna industrija. Gorki okus tkanine”, Privredni vjesnik, 26. 11. 1970., 19; „Prosperitet je daleko, da li i nedostižan?”, Privredni vjesnik, 5. 3. 1970., 6.

106 HOFFER, KOMAN, „Sadašnje stanje i perspektiva tekstilne industrije Jugoslavije”, 426.

107 „Tekstilna industrija. Ni ‘krpice’ u izvozu?”, Privredni vjesnik, 5. 11. 1970., 2. 
odnosu na ostale industrije, loša situacija u tekstilnoj industriji vidljiva je iz niskih ulaganja u stanogradnju jer je zagrebačka tekstilna industrija svojim radnicama osiguravala tek jedan stan na 3000 radnica, a u izgradnji stanova za svoje radnike prednjačile su tada rastuće industrije nafte i plina. ${ }^{108}$ Proizvodni kapaciteti uvelike su nadilazili potrebe domaćega tržišta te se rješenje problema tražilo u ukupnom izvozu, u kojem je tekstilna industrija sudjelovala sa $13 \%$. Gomilale su se zalihe gotovih proizvoda, posebice konfekcije. Na tekstilnu industriju krajem 60 -ih i početkom 70 -ih odražavale su se mjere Saveznoga izvršnog vijeća vezane uz promjene deviznoga i vanjskotrgovinskoga režima, smanjenje broja zaposlenih i postojećih kapaciteta. Hrvatski tekstilni radnici bune se protiv slobodnijih mjera tržišta koje zastupa Savezno izvršno vijeće, traže zaštitu, tj. da se njihovo poslovanje veže uz režim vezivanja uvoza za izvoz jer će u suprotnom biti prisiljeni obustaviti proizvodnju tekstila i konfekcije za izvoz sa svim posljedicama. ${ }^{109} \mathrm{O}$ problemima tekstilne industrije raspravljalo se i u Saveznoj privrednoj komori. Tekstilci su predložili mnoštvo mjera da bi tekstilnoj industriji olakšali položaj s obzirom na carine, smanjenje poreza na promet, deviznu politiku, ukidanje saveznoga poreza, smanjivanje poreza na tkanine od celuloznih i vunenih vlakana. Tadašnju situaciju najbolje sažima rečenica: „Valja kazati da orijentacija na investiranju u tekstil, samo zato da bi se stvorilo novo radno mjesto, olakšao prijelaz iz sela u grad, tekstilcima u cjelini nije donijela mnogo sreće." ${ }^{110}$ Unatoč ozbiljnim upozorenjima i suprotno proklamiranom tržišnom načelu, zapošljavanje je nastavljeno, pa je tekstilna industrija 1971. zapošljavala oko 250000 radnika, što je činilo petinu svih zaposlenih u industriji. ${ }^{11}$ Tih je godina među tekstilcima prevladavalo mišljenje da je tekstilna industrija, koja je „nosila teret jugoslavenske izgradnje”, postala „napuštena grana” od koje „su svi digli ruke”, a banke ih ne kreditiraju jer nisu akumulativni. ${ }^{112}$

Na Proljetnom zagrebačkom velesajmu 1972., premda su tekstilni proizvođači imali pripremljene proizvode za dvije sezone unaprijed, bilo je očito da je konkurencija sve jača, i domaća i inozemna: „[...] domaći tekstil, napose konfekcija, biju sve teži boj s inozemnim konkurentima i bojno polje je unutar i izvan naših granica."113

\footnotetext{
108 RUBIĆ, Nezaposleni u gradu, 120.

109 „Tekstilna industrija. Ni 'krpice' u izvozu?”, Privredni vjesnik, 5. 11. 1970., 2; RADELIĆ, Hrvatska u Jugoslaviji 1945. - 1991., 413-415.

110 „Prosperitet je daleko, da li i nedostižan?”, Privredni vjesnik, 5. 3. 1970., 6.

111 „Moda - greda za utopljenika: Tekstilna industrija”, Privredni vjesnik, 11. 9. 1971., 2.

112 „Gdje su čvorovi nesporazuma? Stjepan Mikša: 'Tekstilci napuštena grana”, Privredni vjesnik, 28. 1. 1971., 2.

113 „Tekstil: U korak s modom”, Privredni vjesnik, 18. 4. 1972., 2.
} 


\section{Zaključak}

Iako se o 60-ima govori kao o zlatnom dobu ekonomije, mode i nagoviještenih političkih sloboda u Jugoslaviji, u ovom tekstu prikazan je mali dio naličja toga vremena i stvarna situacija u tekstilnoj industriji. Na nju smo ukazale analizirajući probleme u proizvodnji metražnoga tekstila, koji je tada činio i veći dio tekstilne industrije.

Šezdesete godine XX. stoljeća u industrijskoj je proizvodnji tekstila i konfekcije obilježilo postupno prelaženje od planske prema tržišnoj ekonomiji. Već od kraja 50-ih primjetno je davanje važnosti tržištu: usmjerava se veća pozornost na prezentaciju metraže na sajmovima, osobito na Zagrebačkom velesajmu, te u trgovinama, koje sada omogućuju kupcima da sami na policama izbliza pogledaju i opipaju tkaninu, odaberu dezen i boju. Istodobno počinje angažman arhitekata na uređenju trgovina i posebno izloga s tkaninama.

Međutim, ova slika koja sugerira konzumerizam i moderan dizajn pripada promidžbi i nije odraz stvarnoga stanja u tekstilnoj industriji. Radom na ovoj temi uočene su sličnosti u problematici i dinamici rada i razvoja tekstilne industrije u međuraću i tijekom 60 -ih godina. Opće karakteristike kao što su veliki uvoz, neobrazovana, uglavnom ženska radna snaga, mala primanja, zastarjeli strojevi ostat će dominantni problemi i nakon Drugoga svjetskog rata. Kronološki pregled obrađenih tiskovina jasnije je pokazao utjecaje političkih i ekonomskih događaja na razvoj i poslovanje tekstilne industrije. Pritom se mogu uočiti utjecaji tzv. male reforme iz 1961., privredne reforme iz 1965. te procesa oprezne liberalizacije gospodarstva kasnih 60-ih. Uočljiva je razlika između prve i druge polovine 60 -ih godina. Prvu je obilježila proizvodnja teških vunenih tkanina za izradu gornjih dijelova ženske i muške odjeće, posebno kaputa. Tekstilna industrija sporo se, ali ipak, prilagođava tržištu svojim preustrojem, odnosno pokušajima udruživanja, mijenjanjem asortimana, a od teških prelazi na lagane umjetne tkanine. Istodobno se otvara vanjskom tržištu, uz niz problema vezanih za uvoz loših sirovina i gotovih tkanina, kao i izvoz vezan uz održanje jeftine cijene rada. $U$ tom je razdoblju znatan problem bonifikacija i trgovina uvoznim tekstilom na crnom tržištu. U drugoj polovini 60 -ih, a u skladu s inozemnim trendovima, naglasak je bio na proizvodnji tkanina od umjetnih vlakana koje se lakše održavaju, jeftinije su i iskazuju nova društvena stremljenja, osobito olakšavanje života zaposlenim ženama.

Od 1965. do 1971. u tekstilnoj metražnoj industriji uočavaju se pojačani zahtjevi za prelazak na tržišno poslovanje, ali je i dalje vidljiv jak utjecaj države. Prvo, kao ustupak ideologiji, ali i socijalnome miru, nastojalo se postići punu zaposlenost te razviti industriju i gradove, što je dovelo do prekomjernoga i potpuno netržišnoga zapošljavanja. Drugo, država se preko zakonodavstva izravno miješala u poslovanje (npr. zakonska regulativa o obveznom izvozu). Treće, jugoslavenskom međunarodnom politikom nesvrstanih osiguravan je 
izvoz nekonkurentih proizvoda, ali istodobno se u gospodarskom vezanju za Zapad uočavaju svojevrsni neravnopravni odnosi (prisila uvoza mnogo robe, među kojom je bilo dosta loše, a jeftinoga izvoza omogućenog jeftinom radnom snagom). Nedovoljno ulaganje u modernizaciju, zato što prihod odlazi u plaće, dovodi do nekonkurentnosti na tržištu u novom vremenu moderne industrije i konzumerizma.

Zaključno se može utvrditi da su, unatoč svim modernizacijskim i liberalizacijskim procesima, zastarjela tehnologija, nekvalificirana ženska radna snaga i najmanja primanja među svim industrijama bili trajan problem metražne tekstilne industrije od 1959. do 1971. godine. Da bi se upotpunila i zaokružila slika zagrebačke i hrvatske tekstilne metražne industrije u razdoblju Socijalističke Federativne Republike Jugoslavije, potrebno je u nekim budućim istraživanjima detaljnije obraditi razdoblje od 1945. do 1959. i od 1971. do 1991. godine. 


\section{Objavljeni izvori i tisak}

15 dana (Zagreb), 1960.

„Apretura”. U: Hrvatska enciklopedija (mrežno izdanje). Leksikografski zavod „Miroslav Krleža”. Pristup ostvaren 21. 7. 2020. http://www.enciklopedija.hr/Natuknica.aspx?ID=3404.

BONFIGLIOLI, Chiara. A Working Day that has no End. The Double Burden in Socialist Yugoslavia. Portal Europäische Geschichte. Pristup ostvaren 10. 4. 2019. https://www.europa.clio-online.de/essay/id/artikel-4168.

„Bonifikacija”. U: Hrvatska enciklopedija (mrežno izdanje). Leksikografski zavod „Miroslav Krleža”. Pristup ostvaren 21. 7. 2020. http://www.enciklopedija.hr/Natuknica.aspx?ID=8673.

„Dàmping”. Hrvatski jezični portal. Pristup ostvaren 13. 11. 2020. http:// hjp.znanje.hr/index.php?show=search_by_id\&id=f1lnXhc\%3D.

Dokumentacija Muzeja za umjetnost i obrt, Inventarna knjiga br. 6.

EIGNER, Peter. „Pollack von Parnegg, Leopold Freiherr”. U: Neue Deutsche Biographie (mrežno izdanje). Pristup ostvaren 29. 5. 2020. https://www. deutsche-biographie.de/pnd139219692.html\#ndbcontent.

Elle - Ona (Ljubljana), 1969, 1971.

Globus (Zagreb), 1960, 1963.

„Gradl”. U: Hrvatska enciklopedija (mrežno izdanje). Leksikografski zavod „Miroslav Krleža”. Pristup ostvaren 15. 7. 2020. http://www.enciklopedija.hr/ Natuknica.aspx?ID=22983.

„Indantrenske boje”. U: Proleksis enciklopedija (mrežno izdanje). Pristup ostvaren 26. 7. 2020. https://proleksis.lzmk.hr/27890/.

„Jacquard, Joseph Marie”. U: Hrvatska enciklopedija (mrežno izdanje). Leksikografski zavod „Miroslav Krleža”. Pristup ostvaren 23. 7. 2020. http:// www.enciklopedija.hr/Natuknica.aspx?ID=28462.

„Kalentić, Marija”. Portal Dizajnerice: kontekst, produkcija, utjecaji 1930 - 1980. Pristup ostvaren 19. 1. 2019. http://www.dizajnerice.com/profile/kalentic-marija/.

„Kamgarn”. U: Proleksis enciklopedija (mrežno izdanje). Pristup ostvaren 21. 7. 2020. https://proleksis.lzmk.hr/29843/.

„Kord-samt”. Hrvatski jezični portal. Pristup ostvaren 15. 7. 2020. http:// hjp.znanje.hr/index.php?show=search_by_id\&id=ellmURU\%253D.

„Krep”. U: Hrvatska enciklopedija (mrežno izdanje). Leksikografski zavod „Miroslav Krleža”. Pristup ostvaren 21. 7. 2020. http://www.enciklopedija.hr/ Natuknica.aspx?ID=33885.

MICHEL, Karl Heinz. „Century Of Success”. Portal Textile World. Pristup ostvaren 26. 7. 2020. https://www.textileworld.com/textile-world/textile-news/2001/02/century-of-success/. 
MILAT, Andrea. „Spora smrt tekstilne industrije”. Portal Le Monde diplomatique, hrvatsko izdanje (arhiva 2013-2017). Pristup ostvaren 28. 5. 2020. https://arhivalmd.wordpress.com/2013/08/27/spora-smrt-tekstilne-industrije/ amp/.

„Popelin”. U: Hrvatska enciklopedija (mrežno izdanje). Leksikografski zavod „Miroslav Krleža”. Pristup ostvaren 21. 7. 2020. http://www.enciklopedija. hr/Natuknica.aspx?ID=49459.

POPOVIĆ, Bojana. „Odsek za savremenu primenjenu umetnost: Marama sa motivom Apolo 8". Zbornik Muzeja primenjene umetnosti Beograd 6 (2008): 208. Pristup ostvaren 19. 3. 2019. https://www.mpu.rs/zbornik/pdf/ zbornik_6/22.pdf.

Privredni vjesnik (Zagreb), 1959-1961, 1965-1966, 1968, 1970-1972.

„Streichgarn”. Wikipedia Die freie Enzyklopädie. Pristup ostvaren 21. 7. 2020. https://de.wikipedia.org/wiki/Streichgarn.

Svijet (Zagreb), 1958, 1965-1966, 1968, 1971.

„Tvid”. U: Hrvatska enciklopedija (mrežno izdanje). Leksikografski zavod „Miroslav Krleža”. Pristup ostvaren 21. 7. 2020. http://www.enciklopedija.hr/ Natuknica.aspx?ID=62859.

Vjesnik u srijedu (Zagreb), 1959-1960, 1963-1965, 1968.

„Zagrebška tekstilna tovarna TVORPAM”. Portal Dolenjski list. Pristup ostvaren 19. 1. 2019. https://www.dolenjskilist.si/media/arhiv-pdf/dl/1963/ DL_1963_02_28_8_674.pdf.

\section{Literatura}

A. K. „Deset godina tekstilnog školstva u Zagrebu”. Tekstil 20 (1971), br. 12: 1036-1038.

ARČABIĆ, Maja. Žuži Jelinek: ambasador mode. Zagreb: Muzej grada Zagreba, 2008.

BIOČINA, Ivana. Proizvedeno u Hrvatskoj. Tranzicija hrvatske tekstilne industrije. Zagreb: Naklada Jesenski i Turk, 2018.

BRKIĆ-MILINKOVIĆ, Misijana. „Nije dočekala Četvrtak...: Vera Antunović (1938. - 2008.)”. Motrišta: glasilo Matice hrvatske Mostar (2008), br. 44: 126.

ČULJAK, Ivana; VENE, Lea. „Žena u borbi / Žena u modi. Odjevne prakse u poslijeratnom periodu socijalističke Jugoslavije na primjeru časopisa 'Žena u borbi' i 'Naša Moda”'. Etnoantropološki problemi 11 (2016), br. 1: 159-173.

DUDA, Igor. Pronađeno blagostanje. Zagreb: Srednja Europa, 2014.

DUDA, Igor. U potrazi za blagostanjem. Zagreb: Srednja Europa, 2005.

HOFFER, Dragutin; KOMAN, Andrej. „Sadašnje stanje i perspektiva tekstilne industrije Jugoslavije". Tekstil 6 (1970): 425-429.

JAKIR, Aleksandar. „Nemoguća misija i početak kraja? Gospodarske reforme u SFR Jugoslaviji tijekom 1960-ih godina”. U: Pogledi 4. Iz hrvatske po- 
vijesti 20. stoljeća - Iz hrvaške zgodovine 20. stoletja, ur. Iskra Iveljić, Stjepan Matković i Žarko Lazarević. Ljubljana: Inštitut za novejšo zgodovino, 2012, 91-110.

KLOBUČAR, Andrea. „... u dobru i zlu...”Vjenčana odjeća od 1865. do danas. Zagreb: Muzej za umjetnost i obrt, 2015.

KOLAR DIMITRIJEVIĆ, Mira. Radni slojevi Zagreba od 1918. do 1931. Zagreb: Institut za historiju radničkog pokreta Hrvatske, 1973.

KOLAR DIMITRIJEVIĆ, Mira. „Zagrebačke tvornice svile s osvrtom na klasnu i oslobodilačku borbu radništva do nacionalizacije”. Povijesni prilozi 7 (1988), br. 7: 77-136.

LEDIĆ, Vesna; PRLIĆ, Adriana; VUČIĆ, Miroslava, ur. Šezdesete u Hrvatskoj: mit i stvarnost. Zagreb: Muzej za umjetnost i obrt; Školska knjiga, 2018.

MAKSIĆ, Maja; MATOŠEVIĆ, Andrea. „Kad si opušten, tada možeš dati sve od sebe': etnografija rada u pulskoj Arena trikotaži”. Narodna umjetnost 55 (2018), br. 1: 95-110.

MATEŠ, Antun. Šezdesete u Zagrebu. Generacija 1965.-1969. Maturanti Škole primijenjene umjetnosti, diplomanti akademije likovne umjetnosti $i$ život u Zagrebu u to vrijeme. Zagreb: Večernji list, 2015.

MIHALJEVIĆ, Josip. „Ekonomska povijest u Časopisu za suvremenu povijest (1969. - 2018.)". Časopis za suvremenu povijest 51 (2019), br. 3: 741-784.

MIHALJEVIĆ, Josip. Komunizam i čovjek. Odnos vlasti i pojedinca u Hrvatskoj (1958. - 1972.). Zagreb: Hrvatski institut za povijest, 2016.

MIHALJEVIĆ, Josip. „Liberalizacija 1960-ih - podloga Hrvatskog proljeća". U: Hrvatska i Hrvatsko proljeće 1971. Zbornik radova, ur. Igor Zidić. Zagreb: Matica hrvatska, 2017, 263-277.

MILJAN, Zrinka; MIHALJEVIĆ, Josip. „Ivanec kao eksperimentalna lokacija jugoslavenske samoposlužne trgovine". Radovi Zavoda za hrvatsku povijest Filozofskoga fakulteta Sveučilišta u Zagrebu 48 (2016), br. 1: 353-385.

PAVIŠIĆ, Tomislav. Spomenica desetgodišnjice osnutka poduzeća Tekstilpromet - Zagreb 1949-1959. Zagreb: Tekstilpromet Zagreb, 1959.

PAVLINUŠIĆ, Jelena, ur. Što je nama naša Dalmatinka dala? Tvornica $i$ predionica konca Dalmatinka - Sinj. Sinj: Kulturno umjetničko središte Sinj, 2017.

PETROVIĆ LEŠ, Tihana; KLOBUČAR, Andrea. „Nähen als informelle Ökonomie im Zagreb der 1960er Jahre”. Jahrbuch für europäische Ethnologie. Kroatien (2019), br. 14: 113-129.

„Potrošački krediti za kupovanje tekstila”. Tekstil 8 (1959), br. 7: 604.

PREMUŽ ĐIPALO, Vedrana. „Žene u doba socijalizma. Slučaj 'Dalmatinka". Ethnologica Dalmatica (2016), br. 23: 159-192.

RADELIĆ, Zdenko. Hrvatska u Jugoslaviji 1945. - 1991. Od zajedništva do razlaza. Zagreb: Školska knjiga; Hrvatski institut za povijest, 2006. 
RUBIĆ, Tihana. Nezaposleni u gradu. Antropologija rada i neformalne ekonomije. Zagreb: Hrvatsko etnološko društvo, 2017.

SENJKOVIĆ, Reana. „Ugljen i šminka. Narativi o jugoslavenskoj radnici na ponudi posttranzicijskom sjećanju”. Etnološka tribina: godišnjak Hrvatskog etnološkog društva 48 (2018), br. 41: 174-193.

SIMONČIČ, Katarina Nina. „Modni boom - revolucija modnih izričaja”. U: Šezdesete u Hrvatskoj: mit i stvarnost, ur. Vesna Ledić, Adriana Prlić i Miroslava Vučić. Zagreb: Muzej za umjetnost i obrt; Školska knjiga, 2018, 328-355.

SIMONČIČ, Katarina Nina. „Modni oglas - memorijski zapis tekstilne i odjevne produkcije Varteksa”. U: Stoljeće tekstila 1918. - 2018., ur. Spomenka Težak. Varaždin: Gradski muzej Varaždin, 2018, 45-74.

ŠIMONČIĆ-BOBETKO, Zdenka. „Razvoj tekstilne industrije u Hrvatskoj u razdoblju između dva svjetska rata (1918-1941)". Povijesni prilozi 1 (1982), br. 1: 101-203.

„Tekstil i konfekcija”. Tekstil 7 (1958), br. 8: 708.

Tekstil 7 (1959), br. 2: 2.

TEŽAK, Spomenka, ur. Stoljeće tekstila 1918. - 2018. Varaždin: Gradski muzej Varaždin, 2018.

ŽEBEC ŠILJ, Ivana. Zagrebačka industrija 1935. - 1939. u kontekstu meduratnog gospodarskog razvoja. Zagreb: Institut društvenih znanosti Ivo Pilar, 2017. 


\section{SUMMARY}

\section{'The Bitter Taste of Fabric': The Zagreb and Yugoslav Textile Industry of the 1960s in Light of Selected Croatian Printed Media}

In this paper, the authors examine the yard goods industry in Zagreb in the 1960s, in the context of the Yugoslav textile industry. Due to the complexity of the textile industry as a topic, the paper examines a longer period, from the late 1950s to the early 1970s, as it has been accepted in historiography.

Using an analytical-interpretative method, qualitative and quantitative results have been obtained from newspapers and journals from 1959 to 1972. A chronological overview of the studied periodicals has shown more clearly the impressions of the political and economic events on the development and business of the textile industry. The influences of the so-called 'small reforms' of 1961, the economic reform of 1965, and the events of 1968 and the subsequent liberalisation process are noticeable. The difference between the first and second half of the 1960s is particularly prominent. The first half was characterised by the production of heavy woollen fabrics for making women's and men's tops, particularly coats. The textile industry was slow to adapt to the market through its reorganisations, i.e. attempts to merge, change product ranges, and switch from heavy to light, artificial fabrics. Simultaneously, there was a reorientation towards foreign markets, which had numerous problems related to the import of poor raw materials and finished fabrics as well as exports aimed at keeping labour costs low. Other significant problems were bonification and the trading of imported textiles on the black market. In the second half of the decade, following international trends, the focus was on producing textiles from artificial fabrics, which were easier to maintain, cheaper, and expressed new social trends, especially making the lives of employed women easier.

In the 1965-1971 period, stronger demands to transition to a market-based business model are evident in the yard goods industry, but a strong influence of the state is also visible in various aspects: firstly, through ideology, as there was an effort to achieve full employment, develop industry and cities, which led to overemployment and employment that was not in line with the needs of the market; secondly, through direct interference in business activities via legislations, such as the regulations on compulsory export; thirdly, through the Yugoslav international policy of non-alignment, but maintaining simultaneous economic links with the West, which led to unequal relationships (forced import of large quantities of goods, much of them of poor quality, and cheap exports). Insufficient investment in modernisation, which was the result of income being diverted to salaries, led to a lack of competitiveness on the new consumer market. This paper concludes that, despite all modernisation and liberalisation processes, obsolete technology, an unqualified female workforce, and the lowest income among all industries were permanent problems of the yard goods industry from 1959 to 1971.

Key words: textile industry; Yugoslavia; Zagreb; printed media; economic history; 1960s 